\title{
Systematic Tracking of Malaysian Primary School Students' ESL Reading Comprehension Performance to Facilitate Instructional Processes
}

\author{
Lin Siew Eng \\ Senior Lecturer, School of Educational Studies, University Sains Malaysia \\ selin@usm.my
}

\author{
Abdul Rashid Mohamed \\ Dean, School of Educational Studies, University Sains Malaysia, rich@usm.my \\ Shaik Abdul Malik Mohamed Ismail \\ Deputy Dean of Academic, School of Educational Studies, University Sains Malaysia \\ samalik@usm.my
}

$\mid$

This study was conducted to systematically track and benchmark upper primary school students' ESL reading comprehension ability and subsequently generate data at the micro and macro levels according to individual achievement, school location, gender and ethnicity at the school, district, state and national levels. The main intention of this initiative was to provide information to assist ESL teachers about their students' reading ability and to determine students' reading comprehension performance standards. The auto generated data is expected to facilitate classroom instructional process without necessitating teachers to prepare test materials or manage data of their students' reading comprehension track records. The respondents were 1,514 Year 5 students from urban and rural schools from a district in northern Malaysia. The idea was conceptualised through a series of tests and development of the Reading Evaluation and Decoding System (READS) for Primary Schools. The findings indicated that majority of the respondents were 'below standard' and 'at academic warning'. We believe the generated data can assist the Ministry of Education to develop better quality instructional processes that are evidence based with a more focused reading instruction and reading material to tailor to the needs of students.

Keywords: benchmark, reading ability, reading evaluation, decoding, instructional process

\section{INTRODUCTION}

Reading comprehension is a necessary component of any language test. This is not surprising as this is a very important skill that the learners must master to assist in pursuing knowledge. In the teaching and learning of any skill, evaluation is an 
inseparable element that is often considered 'evil but necessary'. However, most assessment done by teachers is merely to discriminate who among the learners are performing better than others. Generally, English language teachers lament that the grades alone are insufficient to indicate the learners' levels of reading ability accurately. Though the learners may have the same grade, it does not necessarily mean that the learners possess the same level of reading proficiency. Zwiers (2005) feels that clear feedback is needed to inform learners of their progress. In fact, there is more to assessments than just assigning of grades. Black and William cited in Boston (2002) broadly define assessments to include all activities that teachers and students undertake to get information that can be used diagnostically to alter teaching and learning. Similarly, Lambert and Lines (2000:4) define assessment as "the process of gathering, interpreting, recording and using information about pupils' responses to educational tasks".

According to Masters (2006, 2014), the main purpose of the assessment when learning is viewed as an on-going process that transcends particular teachers and grades, would be to establish where in their learning where the individuals are at a particular time in a particular learning area. When the assessments are conducted for the purpose of establishing where the individuals are in their on-going learning, it is referred to as the assessment of learning. Similarly, Earl (2003) believes that assessment for learning offers an alternative perspective to traditional assessment in schools and it shifts the emphasis from summative to formative assessment, from making judgments to creating descriptions that can be used in the service of the next stage of learning. All the activities that are carried out by the teacher are designed not to make comparative judgments among the students' achievements, but to highlight the students' strengths and weaknesses and provide them with the feedback that will further their learning.

Test scores should furnish teachers with reliable analytical information of what students do or do not know and can or cannot do, and subsequently may assist teachers to prepare more tailored reading comprehension instruction to their students. Such test scores should also allow teachers to determine where the students' position is in their reading development. Teachers of English as a second language are often asked to teach and evaluate their students' abilities in reading. The current evaluation system in Malaysian primary schools merely tests pupils' comprehension through what some would argue are outmoded and imprecise instruments that merely reveal the pupils' test scores on those tests and nothing more.

The current practice of reading evaluation could perhaps be improved to provide more information about learners' reading abilities. Based on this precinct, the researchers developed a Reading Evaluation and Decoding System (READS) as an alternative evaluation system. It is important to design assessments to inform (be for learning) and improve learners' performance. It is timely that teachers generally integrate assessment with teaching instruction. Thus, the objective of READS is to benchmark learners' reading comprehension ability precisely and accurately as well as generate data at the micro and macro levels according to individual achievement, school location, gender, and ethnicity at the school, district, state and national levels. This information will 
provide teachers and planners with a wealth of data and subsequently will assist them to make evidence-based and informed decisions about the manner teaching of reading and comprehension should be done.

\section{REVIEW OF LITERATURE}

Assessment is an ongoing process which encompasses a much wider domain (Brown, 2004). Popham (1999) states that assessment is essential in a teaching and learning process and the purpose of assessing the students is to determine each individual's strength and weakness. It also helps teachers to determine whether their students are progressing satisfactorily or are not progressing satisfactorily. Similarly, Kubiszyn and Borich (1996) define the term 'assessment' as the process of collecting data for the purpose of specifying and verifying problems and thus, making decisions about students. Besides, Stiggins (2008) also defines assessment as the process of gathering evidence of students' learning progress to inform instructional decisions. Since assessment is an integral part of the teaching and learning process, it should be aligned with the teaching instructional plan. Weeden et al. (2002) state that teachers could use the information they obtained from assessment results to plan and teach their lessons. There is an alignment between assessment, teaching and learning. Thus, teachers need to identify and monitor students' reading ability so that they can adjust their teaching to meet the needs of their students and provide relevant stretch goals (Masters, 2014).

\section{About the System and its Potency to Assist Instruction}

READS, is an acronym for Reading Evaluation and Decoding System. READS is the first of its kind in the Asian region and it was developed based on rigorous research, established reading theories, mandated Malaysian school curriculum and official syllabus documents. One of the eminent potential of READS is its problem detection and solving capabilities. READS problem solving capabilities are copious as it can assess learners' reading comprehension ability and determine learners' performance standards.

The system contains three components: the Encoder (the Test Instrument), the Analyser (the Reading Matrix) and, the Decoder (the Reading Indicators).

i) Encoder: The Test Instrument or Encoder is a generic test which can be used to measure the ESL reading performance of upper primary school students from Year 4 to Year 6. This test comprises of 50 multiple choice questions. There are 12 elementary level comprehension questions which constituted $25 \%$ of the test, 24 intermediate level comprehension questions which constituted $50 \%$ of the test and 14 advanced level comprehension questions which constituted $25 \%$ of the test. The comprehension questions comprise of three of the major classifications of comprehension abilities as found in the Taxonomy of Reading Comprehension proposed by Barrett (cited in Alderson and Urquhart, 1984) namely literal, reorganisation and inferential comprehension questions.

ii) The Analyser: The Reading Matrix or Analyser is a user-friendly chart where the teachers can match their students' test scores with the Performance bands indicated in the chart as plotted against the educational levels. The idea of Progression through the 
levels advocated by the Task Group on Assessment and testing (TGAT) Report (1988) cited in Horton (1990) and Masters (2006) in which the criteria of levels of proficiency and age were taken into consideration in gauging the students' progress was adopted to develop the Reading Matrix.

iii) The Decoder: The Reading Indicators or Decoder acts as indicators to inform the teachers about which sub-skills of reading the students can do or cannot do. These indicators were developed based on the respondents' reading performance on the conducted test. North's 'Reading Scale for the Council of Europe Framework' cited in Alderson (2000: 132-134) was adopted as the model to develop the Reading Indicators.

The potency of the Reading Indicators is in its ability to provide ESL teachers with a reference point to gain accurate information of their students' reading abilities at the micro and macro level and accordingly teachers can plan their teaching instruction and select appropriate reading materials to meet the needs of the students.

\section{THE STUDY}

This study was conducted to trial an instrument to benchmark students' reading ability precisely and accurately as well as to generate data at the micro and macro levels.

\section{Respondents}

In this study, 1514 Year 5 students from 13 urban schools and 19 rural schools from a district in Northern Malaysia comprising of students of high proficiency, mid proficiency and low proficiency participated.

\section{The Pilot Study}

Initially a pilot study was conducted in a district in Northern Malaysia. As many as 299 respondents of Year 4 (76 students), Year 5 (107 students), and Year 6 (116 students) were involved in the pilot study. A prototype system was first devised based on the Malaysian school curriculum. A model encoder was developed and it was piloted. The pilot study allows the researcher to obtain the test validity and reliability. The pupils' performance was used to develop the Analyser. Based on the prototype Encoder and Analyser, the Decoder was developed. The Decoder was developed based on the quantitative and qualitative data gathered from the pupils who took part in the study. The three components of READS were comprehensively calibrated and refined further through more tests for accuracy. It was found that READS has been proven to be accurate in establishing learners' reading ability and is a very reliable system to evaluate pupils' performance and decode their reading abilities.

\section{Procedure of Study}

This study involved a number of stages. A number of activities were conducted in each stage. The stages are as follow:

\section{Developing Standardised Reading Comprehension Test}

A set of 50 multiple choice reading comprehension questions comprising of 12 elementary, 24 intermediate and 14 advanced level questions were involved. The validity of the SRCT was checked by 3 content experts who are experienced examiners, 
a senior ESL teacher and a university lecturer. This test has a reliability of 0.85 (KR20). This fulfils the quality of a highly-reliable test.

Developing cut scores for bands

The scores obtained from the pilot study are used to categorise the respondents in order to determine the reading proficiency of the students. The respondents were categorised into four bands based on Barrett's Taxonomy of Reading Comprehension cited in Day and Park (2005), Bloom's Taxonomy cited in Anderson et al. (2001) and the Malaysian English Language Syllabus (2003). To develop the range of scores between bands, the researcher used z-scores to develop the cut score. In this study, cut score was used to categorise the respondents into four bands (Band 1,2,3, and 4) as it could determine students' reading ability. To develop the cut score, the researcher decided to use $\mathrm{z}$ scores. According to Carey (2001), z-score determines how much a point deviates from the mean. Gronlund (2006) stated that z-scores indicate a number of standard scores in standard deviation units. It determines how far a given raw score is above or below a mean.

Cut scores for the bands of this study are as follow:

Band $1 \quad: \quad 0-12$ marks

Band $2 \quad: \quad 13-20$ marks

Band $3 \quad: \quad 21-28$ marks

Band $4 \quad$ : $\quad 29-50$ marks

Administering the standardised reading comprehension test and questionnaire

The developed standardised written reading comprehension test was administered to determine the respondents' ESL reading abilities. The researcher collected the data together with the demographic information to be coded and the data were keyed into the SPSS (version 20).

\section{Qualitative Study}

The researcher conducted interviews with students who obtained Band 1 to Band 4 . Structured interviews were used to carry out qualitative research. The data was then used to inform the development of the Reading Indicators.

\section{Analysing Test Scores}

This study required quantitative data and it was used to develop the bands based on the scores gained from the test. Students' ESL reading proficiency was indicated by the different bands (Band 1 to Band 4). The data that was gathered and analysed were stipulated in the forms of frequency and percentage using the SPSS (version 20).

Developing Reading Performance Standards

In benchmarking Year Five students' reading abilities, the development of reading performance standards is one of the fundamental issues. The concept of British Columbia Performance Standards (BCPS) (2013) was adapted to develop the reading performance standard as the framework reflects the prescribed learning outcomes of the learners and thus, provide teachers with many opportunities to assess these learning outcomes. 


\section{Developing Reading Indicators}

Indicators of reading ability based on the students' reading proficiency developed will allow the teachers to have a clear idea about whether the students have or have not mastered the sub-skills of reading comprehension by referring to each of the bands. The indicators of the reading ability serve as a handy and practical diagnostic tool for determining ESL students' reading abilities as it clearly identifies students' strengths and weaknesses. In order to provide teachers and students with a set of detailed reading indicators, several resources on reading descriptors or indicators were referred to by the researchers namely, 'Reading Performance Descriptors' adopted by South Dakota Department of Education (2014) and the Achievement Level Descriptors by Minnesota Department of Education (2013).

\section{HOW READS WORKS}

Teachers who intend to use READS need to adhere to the following steps (Figure 1):

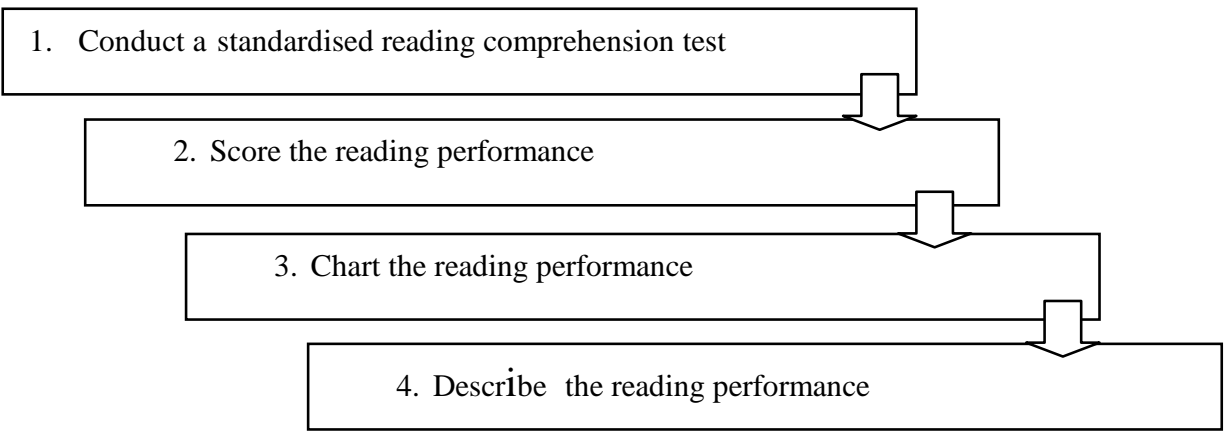

Figure 1: How READS Works

\section{The Standardised Reading Comprehension Test}

Conduct the Standardised Reading Comprehension Test. Time allocated for the test is 60 minutes.

\section{Scoring the Reading Performance}

Use the test scores to identify the students' reading abilities. The total available score in the test is 50 marks. From the test scores, the students are categorised into the various bands (Band 1 to Band 4).

Table 1: Performance Bands and Performance Standards for Year 5 students

\begin{tabular}{lcccc}
\hline Bands & 1 & 2 & 3 & 4 \\
\hline \multirow{2}{*}{ Scores } & $0-12$ & $13-20$ & $21-28$ & $29-50$ \\
& marks & marks & marks & marks \\
\hline Performance & Academic & Below & Meet & Exceed \\
Standards & Warning & Standard & Standard & Standard \\
\hline \multicolumn{2}{l}{ Total score $=$ 50 marks } & & & \\
\hline
\end{tabular}




\section{Charting the Reading Performance}

Identify the students' reading abilities by using the Reading Matrix. Match the students' reading performance against the Reading Matrix and then correlate them to the Performance Standards and the Reading Indicators of Band 1 to Band 4.

\section{FINDINGS}

\section{Benchmarking Reading Performance}

The first section presents the respondents' reading performance at micro level. This is followed by the general reading performance and the next section is the overall reading performance based on gender, school location and ethnicity at macro level. The final sub-section illustrates the respondents' reading ability to answer the different sub skills of reading according to gender, school location and ethnicity.

Sample of Respondent's Reading Performance (micro level)

Table 2: John's Reading Performance

\begin{tabular}{ccccc}
\hline Name & Year & Score & $\begin{array}{c}\text { Performance } \\
\text { Band }\end{array}$ & $\begin{array}{c}\text { Performance } \\
\text { Standard }\end{array}$ \\
\hline John & 5 & $35 / 50$ & 4 & Exceed standard \\
\hline
\end{tabular}

The findings in Table 2 are a sample of a respondent's Reading Performance (micro level). The data will inform the teacher that John, who is a Year 5 student, obtained 35 marks out of 50 marks. This indicates that John is categorised in Band 4. Year 5 students 'meet standard' at Band 3 (refer to Table 1). Therefore, John 'exceeds standard' by one band. This means that John can read texts at Year 6 level. Thus, the teachers can plan teaching instruction and reading materials appropriate to their students' reading ability. ESL teachers can refer to the Reading Performance Standards and Reading Indicators to identify the specific true reading ability of the students.

\section{Respondents' General Reading Performance (micro level)}

This section presents the respondents' general reading performance. Based on the calculated cut scores, students in Year 5 should be in Band 3 which indicates that they 'meet standard'. However, only $17.5 \%$ from 1514 respondents were categorised in Band 3 , which means only 264 respondents (17.5\%) were identified as 'meet standard'. Nonetheless, 114 respondents $(7.5 \%)$ were at 'exceed standard' as they were categorised in Band 4. 833 respondents $(55.0 \%)$ were at 'below standard' as they were categorised in Band 2. About 303 respondents $(20.0 \%)$ were at 'academic warning' as they were categorised in Band 1. Table 3 charts out the percentages of respondents in each of the performance bands.

Table 3: General Reading Comprehension Performance

\begin{tabular}{cccccccc}
\hline \multicolumn{2}{c}{ Exceed } & Standard & \multicolumn{2}{c}{ Meet Standard } & \multicolumn{2}{c}{ Below Standard } & \multicolumn{2}{c}{ Academic Warning } \\
\hline $\mathrm{f}$ & $\%$ & $\mathrm{f}$ & $\%$ & $\mathrm{f}$ & $\%$ & $\mathrm{f}$ & $\%$ \\
\hline 114 & 7.5 & 264 & 17.5 & 833 & 55.0 & 303 & 20.0 \\
\hline
\end{tabular}

$\mathrm{n}=1514$ students 
Respondents' Overall Gender, School Location and Ethnicity Performance (macro level)

In Table 4, the percentage of female students who performed at 'Exceed standard' and 'Meet standard' was higher than the male students. However, the percentage of male students who performed at 'Below standard' and 'Academic Warning' was higher than the female students. Overall, the female students outperformed the male students. This is similar to the results of Program for International Student Assessment (PISA) where the female Malaysian students performed better than the male Malaysian students (OECD, 2012).

Table 4: Overall Gender, School Location and Ethnicity Performance

\begin{tabular}{lcccccc}
\hline & \multicolumn{2}{c}{ Gender } & \multicolumn{2}{c}{ School Location } & \multicolumn{2}{c}{ Ethnicity } \\
\hline & $\begin{array}{c}\text { Male } \\
(\%)\end{array}$ & $\begin{array}{c}\text { Female } \\
(\%)\end{array}$ & $\begin{array}{c}\text { Urban } \\
(\%)\end{array}$ & $\begin{array}{c}\text { Rural } \\
(\%)\end{array}$ & $\begin{array}{c}\text { Malay } \\
(\%)\end{array}$ & $\begin{array}{c}\text { Non-Malay } \\
(\%)\end{array}$ \\
\hline Exceed Standard & 2.7 & 4.8 & 5.4 & 2.1 & 5.8 & 1.7 \\
\hline Meet Standard & 6.5 & 11.0 & 9.9 & 7.6 & 15.6 & 1.9 \\
\hline Below Standard & 28.1 & 26.9 & 26.4 & 28.6 & 52.4 & 2.6 \\
\hline $\begin{array}{l}\text { Academic } \\
\text { Warning }\end{array}$ & 12.5 & 7.5 & 9.0 & 11.0 & 19.1 & 0.9
\end{tabular}

Key: Exceed standard $=114$ respondents, Meet standard $=264$ respondents,

Below standard $=833$ respondents, Academic Warning $=303$ respondents

With regards to the overall school location performance, the percentage of students who attended schools in the urban areas who performed at 'Exceed standard' and 'Meet standard' was significantly higher than the students who attended schools in the rural areas. Conversely, the percentage of students who attended schools in the rural areas who performed at 'Below standard' and 'Academic Warning' was significantly higher than the students who attended schools in the urban areas. In contrast, a significant higher percentage of fourth-graders and eighth-graders attending schools in suburb and rural areas outperformed students who attended schools in cities and towns in National Assessment of Educational Progress (NAEP) 2013 Reading Assessment (U.S. Department of Education, 2013).

In terms of overall ethnic performance, the percentage of the Malay learners who performed at 'Exceed standard', 'Meet standard', 'Below standard' and 'Academic Warning' was significantly higher than the Non- Malay learners.

\section{Performance of the Different Sub-skills of Reading (macro level)}

Table 5, Table 6 and Table 7 illustrate the respondents' reading performance on the different sub-skills of reading. The measure of central tendency used is the mean score. As we look at the performance of the respondents based on gender for the different subskills of reading i.e. literal, reorganisation and inferential assessed at different difficulty levels (elementary, intermediate and advanced levels), we can see that the mean score of the male students was below the overall mean for the literal and reorganisation comprehension questions. However, Table 7 illustrates that the mean score of the male 
respondents were the same as the overall mean score at the intermediate level in answering the inferential comprehension questions.

From the perspective of school location, the data shows that students from the urban schools performed better than the students in the rural schools when answering the literal, reorganisation and inferential comprehension questions at the different difficulty levels.

Furthermore, Table 5, 6 and 7 shows that the Non Malay students performed better than the Malay students when answering the different types of questions at different difficulty levels.

Table 5: Reading Performance on the Literal Sub-Skill

\begin{tabular}{|c|c|c|c|c|c|c|c|c|c|}
\hline \multirow[t]{2}{*}{$\begin{array}{l}\text { Reading } \\
\text { difficulty } \\
\text { levels }\end{array}$} & \multicolumn{3}{|c|}{ Gender } & \multicolumn{3}{|c|}{ School location } & \multicolumn{3}{|c|}{ Ethnicity } \\
\hline & Male & Female & Overall & $\begin{array}{c}\text { Urba } \\
n\end{array}$ & $\begin{array}{c}\text { Suburba } \\
n\end{array}$ & Overall & Malay & $\begin{array}{l}\text { Non- } \\
\text { Malay }\end{array}$ & Overall \\
\hline Elementary (5) & 2.7 & 3.2 & 3.0 & 3.1 & 2.8 & 3.0 & 2. & 3.7 & 3.3 \\
\hline Intermediate(5) & 1.3 & 1.4 & 1.4 & 1.39 & 1.35 & 1.37 & 1. & 1.7 & 1.6 \\
\hline Advanced (3) & 0.9 & 1.0 & 0.95 & 0.94 & 0.89 & 0.92 & 0. & 1.1 & 1.0 \\
\hline \multicolumn{10}{|c|}{ Table 6: Reading Performance on the Reorganisation Sub-Skill } \\
\hline \multirow[t]{2}{*}{$\begin{array}{l}\text { Reading } \\
\text { difficulty } \\
\text { levels } \\
\end{array}$} & \multicolumn{3}{|c|}{ Gender } & \multicolumn{3}{|c|}{ School location } & \multicolumn{3}{|c|}{ Ethnicity } \\
\hline & Male & Female & Overall & $\begin{array}{c}\mathrm{Urb}_{\mathrm{n}} \\
\mathrm{n}\end{array}$ & $\begin{array}{c}\text { Suburb } \\
n\end{array}$ & Overa & & $\begin{array}{l}\text { Non- } \\
\text { Mala }\end{array}$ & ay Overall \\
\hline Elementary (4) & 1.4 & 1.5 & 1.5 & 1.5 & 1.3 & 0.9 & & 1.9 & 1.7 \\
\hline Intermediate(13) & 4.4 & 5.0 & 4.7 & 4.9 & 4.5 & 4.7 & & 5.4 & 5.1 \\
\hline Advanced (6) & 1.9 & 2.3 & 2.1 & 2.2 & 2.0 & 2.1 & & 2.5 & 2.3 \\
\hline \multirow{2}{*}{$\begin{array}{l}\text { Reading } \\
\text { difficulty } \\
\text { levels } \\
\end{array}$} & \multicolumn{3}{|c|}{ Gender } & \multicolumn{3}{|c|}{ School location } & \multicolumn{3}{|c|}{ Ethnicity } \\
\hline & Male & Female & $\begin{array}{c}\text { Overal } \\
\quad l\end{array}$ & $\begin{array}{l}U r- \\
\text { ban }\end{array}$ & $\begin{array}{l}\text { Subur- } \\
\text { ban }\end{array}$ & $\begin{array}{c}\text { Overal } \\
\quad l\end{array}$ & $\begin{array}{c}\text { Mala } \\
y\end{array}$ & $\begin{array}{c}\text { Non- } \\
\text { Mala } \\
y\end{array}$ & $\begin{array}{c}\text { Overal } \\
\quad l\end{array}$ \\
\hline Elementary (3) & 0.9 & 1.2 & 1.1 & 1.1 & 1.0 & 1.1 & 1.0 & 1.6 & 1.3 \\
\hline \multirow[t]{2}{*}{ Intermediate(6) } & 1.7 & & & & & & & & \\
\hline & 1 & 1.7 & 1.71 & 1.8 & 1.6 & 1.7 & 1.7 & 2.1 & 1.9 \\
\hline Advanced (5) & 1.2 & 1.4 & 1.3 & 1.4 & 1.2 & 1.3 & 1.2 & 1.9 & 1.6 \\
\hline
\end{tabular}

\section{DISCUSSION}

This study benchmarked the students' ESL reading comprehension ability as well as generated data at the micro level (individual) and macro level (groups according to gender, school location and ethnicity). READS is a generic test that was developed for all Malaysian Upper Primary schools from Year 4 to Year 6. Although the students can 
be at the same educational level, their reading ability may differ; even so the Reading Matrix from READS can differentiate the real ESL reading ability of these students. The result showed that more than half of the total number of respondents in Year 5 were categorised as 'below standard' and one fifth of the total number of respondents were categorised as at 'academic warning'. Only a small percentage was classified as 'meet standard'. Therefore, this study suggests that a large number of students in that district are weak in answering the ESL reading comprehension involving the different sub-skills of reading. They have difficulty in understanding the different types of texts as well as answering the comprehension questions at the different difficulty levels.

\section{Reads and its Impact on Teaching and Learning}

Current assessment activities in Malaysian schools in many ways may help teachers with a wealth of feedback information. But this is rather general in nature and may not be capable of providing information about the precise problems faced by learners.

The introduction of READS and the direction of this study are intended to provide a more strategic and systematic mechanism to assist teachers and policy makers with the necessary information at macro and micro levels regarding the use of assessment feedback. For example, at the macro level, policy makers and administrators can observe, monitor and follow learners at the state, district, school and class levels in terms of reading comprehension trends and development. While at the micro level, the school principal and teacher concerned and as well as parents will be able to look at learners' progress in many ways. For example, students who are categorized at Band 4 will be able to answer the literal, reorganisation and inferential questions at ease while students in Band 1 can understand only a few words that they read. These students have difficulty even in answering the literal comprehension questions which is the simplest level of comprehension questions. Such diagnostic information is very useful in targeted strategies to support such students in being given appropriate stretch goals for where they are at in their learning.

Assessment like READS equipped with the necessary management system may provide useful evidence based data for teachers to develop appropriate instructional strategies pinning down the problems learners uncounted and subsequently work on learners' strengths and weaknesses to provide the necessary help. Ground breaking assessment innovation like this as provided by READS is rather new to the Malaysian school setting. It provides an avenue to teachers and administrator alike to pay particular attention to details and provide, using a medical analogy 'the right antidote for the specific kind of sickness'. The information generated from READS management system can be kept over a period of time and learners' progress can be fully monitored. This effort in the long run may impact in the manner formative assessment and should be conducted and the data generated should be utilized.

Teachers in Malaysia have a role to play as advocated by the latest curriculum transformation suggested in the Malaysian Educational Development Plan 2013-2025 that critically advocates the importance of English Language and teachers' professionalism. In line with this transformation plan, the information generated by 
READS management system is geared towards enhancing teachers' professionalism to teach through a well informed assessment process and to teach the right things right. For example, concentration on certain skills in the Barrett's taxonomy may have to be given much more priority than others as reflected in the findings for example: Findings in Table 5, table 6 and Table 7 indicate that majority of the students in Year 5 have difficulty in answering the inferential comprehension questions as compared to answering the literal and reorganisation comprehension questions. Thus, the teachers have to focus on teaching reading skills to help students make inferences and draw conclusions. We foresee that READS along with its management system have its credibility as its usage will eventually be a substantial part of teachers' everyday tool in their classrooms. Learners eventually will be given a relevant instruction and appropriate stretch goals to maximize their learning gains.

\section{CONCLUSION}

The current evaluation system can neither decode the true reading ability of the students nor determine the reading ability of the students. Indeed, it does not provide sufficient information to assist teachers with instruction. Now, ESL teachers can use READS to benchmark students' reading abilities precisely. READS can be used as formative assessment as well as 'assessment for learning' to inform teachers of their students' abilities. It can also be used as summative assessment or 'assessment of learning' to benchmark learners against the norm. The novelty of READS is unprecedented as it is not only a unique assessment tool with a large repository of comprehension texts and questions that can be generated, but READS is also a management system that can assess, grade, and generate sophisticated data useful in decision making by educational professionals. READS will free teachers from endless and unnecessary tasks of grading and record keeping and thus put teachers to work with the core teaching business. Less assessment and more focus on teaching and learning. A bit like the old phrase 'you don't fatten a pig by constantly weighing it'. With READS, we believe that the nationwide upper primary school students' ESL reading comprehension ability can be established. One of the main highlights of READS is that it can readily be used in countries where English is spoken as a second or foreign language in this region.

\section{REFERENCES}

Alderson, J. C. (2000). Assessing reading. Cambridge: Cambridge University Press.

Alderson, J. C. \& Urquhart, A. H. (eds.) (1984). Reading in a foreign language. Essex: Longman.

Anderson, L. W., \& Krathwohl, D. R. (Eds.). (2001). A taxonomy for learning, teaching and assessing: A revision of Bloom's Taxonomy of educational objectives. New York: Longman.

Banks, S. R. (2005). Classroom Assessment: Issues and practices. Boston: Pearson Education, Inc.

Boston, C. (2002). The concept of formative assessment. Practical Assessment Research \& Evaluation, 8 (9). 
British Columbia Performance Standards. (2013). Reading for Information. Province of British Columbia: Ministry of Education of Ministry Columbia. Online. Accessed on 15 November 2015. http://www.bced.gov.bc.ca/perf_stands/reading_g6.pdf

Brown, H. D. (2004). Language assessment: Principles and classroom practices. New York: Pearson Education, Inc.

Burke, K., ed. (1992). Authentic Assessment: A collection._Arlington Heights: IRI/Skylight Training and Publishing, Inc.

Carey, L. M. (2001). Measuring and evaluating school learning (Third ed.). Boston: Allyn and Bacon.

Day, R. R. \& Park, J. (2005). Developing Reading Comprehension Questions. Reading in a Foreign Language, 17(1), 60-73.

Earl, L. M. (2003). Assessment as learning: Using classroom assessment to maximise student learning. Thousand Oaks: Corwin Press.

Horton, T., ed. (1990). Assessment debates. London: Hodder and Stoughton.

Kubiszyn, T., \& Borich, G. (1996). Educational Testing and Measurement: Classrooom Application and Practice. New York: Harper Collins.

Lambert, D. \& Lines, D. (2000). Understanding Assessment: Purpose, perception, practice._London: Routledge.

Massachusetts Department of Education (2003). 2002 NAEP reading results. Malden: Massachusetts Department of Education. Online. Accessed on 5 August 2007. http://www. doe.mass.edu/mcas/naep/results/02naep_read.pdf

Massachusetts Department of Education (2007). 2007 NAEP tests: Summary of results for Massachusetts. Malden: Massachusetts Department of Education. Online Accessed on 20 December 2007. http://www. doe.mass.edu/mcas/naep/results/07read_math.pdf

Masters, G. N. (2006). Continuity and growth: Key consideration in educational improvement and accountability. In a paper presented at 3rd International Conference on measurement and evaluation in education, Penang. 13 -15 February 2006.

Masters, G. N. (2014). Towards a growth mindset in assessment. In a paper presented at Australian Curriculum: Aligning learning areas mini-conference, Brisbane. 22 March 2014.

Minnesota Academic Standards (2013). English Language Arts K-12 2010. Minnesota Department of Education.Online. Accessed on 8 March 2015.http:// education.state.mn.us/MDE/EdExc/StanCurri/K12AcademicStandards/Reading/index.htm

Mullis et al. (2009). PIRLS 2011 assessment framework and specifications. Chestnut Hill, MA: PIRLS International Study Center, Lynch School of Education, Boston College. 
OECD (2002). Reading for change: Performance and engagement across countries. Results from PISA 2000. Paris: OECD Publications.

Organization for Economic Cooperation and Development (OECD) (2012). Program for International Student Assessment (PISA), 2012.Online. Accessed on 15 February 2015. http://nces.ed.gov/surveys/pisa/pisa2012/pisa2012highlights_5c.asp

Popham, W. J. (1999). Classroom assessment: What teachers need to know (Second ed.). Boston: Allyn and Bacon.

South Dakota Department of Education. (2014). Sixth Grade Reading Standards. Pierre. Online. Accessed on 12 January 2015.http://doe.sd.gov/contentstandards/

Stiggins, R. (2008). An introduction to student-involved assessment for Learning (Fifth ed.). New Jersey: Pearson Education Inc.

U. S. Department of Education (2013). National Assessment of Educational Progress (NAEP), 2013 Reading Assessment. Institute of Education Sciences, National Center for Education Statistics. Online. Accessed on 20 December 2014. $\mathrm{http}: / /$ nces.ed.gov/nationsreportcard/statecomparisons/withinyear.aspx?usrSelections=2 $\% 2 \mathrm{cRED} \% 2 \mathrm{c} 0 \% 2 \mathrm{c} 0 \% 2 \mathrm{cwithin} \% 2 \mathrm{c} 0 \% 2 \mathrm{c} 0$ Weeden et al. (2002). Assessment: What's in it for schools? London: Routledge Falmer.

Zwiers, J. (2005). Building reading comprehension habits in grades 6-12: A toolkit of classroom activities. Newark: International Reading Association.

\section{Turkish Abstract}

Öğretim Sürecini İyileștirmek için Malezya İlkokul Öğrencilerinin ESL Okuduğunu Anlama Performanslarının Sistematik Takip Edilmesi

Bu çalışmanın amacı ilkokul öğrencilerinin ESL okuduğunu anlama becerilerini sistematik olarak değerlendirmek ve takip etmek, aynı zamanda bireysel başarı, okul lokasyonu, cinsiyet, etnisiteye göre okulda, bölgede ve ulusal düzeyde micro ve macro düzeyde very oluşturmaktır. Bu girişimin asıl amacı ESL öğretmenlerine ögrencilerin okuma becerileriyle ilgili bilgi sağlamak ve öğrencilerin okuduğunu anlama standartlarını belirlemektir. Otomatik oluşturulan verinin ögretmenlerin değerlendirme için test materyali hazırlamasına ve bunların sonuçlarını tutmalarına ihtiyaç duymadan sınıf içi öğretim sürecini iyileştirmesi beklenmektedir. Katılımcılar şehir ve kırsal okullardan kuzey Malezya'dan 1514 5. sınıf öğrencisidir. Fikir test seti ve İlkokullar için Okuma Değerlendirmesi ve Çözümleme Sistemi (READS) ile kavramsallaştırılmıştır. Bulgular öğrencilerin çoğunun standartların altında olduğunu göstermiş̧tir. Oluşturulan veri eğitim bakanlı̆̆ına öğrencilerin ihtiyaçlarını karşılayacak okuma materyali ve öğretimi odaklı kanıt temelli daha kaliteli öğretim süreçleri geliştirmesine yardımcı olacaktır.

Anahtar Kelimeler: değerlendirme, okuma becerisi, okuma değerlendirmesi, çözümleme, öğretim süreci 


\section{French Abstract}

Dépistage Systématique d'ESL d'Étudiants d'École primaire malais Lecture de Performance de Compréhension pour Faciliter Processus D'instruction

Cette étude a été conduite pour systématiquement suivre à la trace et évaluer ESL des étudiants d'école primaire supérieur la lecture de la capacité de compréhension et produire par la suite des données aux micro et macro niveaux selon l'accomplissement individuel, l'emplacement scolaire, le genre et l'appartenance ethnique à l'école, le quartier, des niveaux d'état et nationaux. L'intention principale de cette initiative était de fournir des informations pour aider des professeurs ESL de la capacité de lecture de leurs étudiants et déterminer les norms de performance de compréhension de lecture des étudiants. On attend à ce que les données produites autos facilitent la salle de classe le processus d'instruction sans nécessiter des professeurs à préparer des matériels de test ou gèrent les données des rapports de trace de compréhension de lecture de leurs étudiants. Les défendeurs étaient 1,514 An 5 étudiants d'écoles urbaines et rurales d'un quartier en Malaisie du nord. L'idée a été conceptualisée par une série de tests et le développement de l'Évaluation Lisante et le Système de Décodage (LIT) pour des Écoles primaires. Les découvertes ont indiqué que la majorité des défendeurs était ' au-dessous de la norme ' et ' à l'avertissement d'universitaire '. Nous croyons que les données produites peuvent aider le Ministère de l'Éducation nationale à développer la meilleure qualité les processus d'instruction qui sont la prevue basée avec une instruction de lecture plus concentrée et un matériel(une matière) de lecture pour adapter aux besoins d'étudiants.

Mots Clés: point de référence, lisant capacité, lisant évaluation, décodage, processus d'instruction

\section{Arabic Abstract}

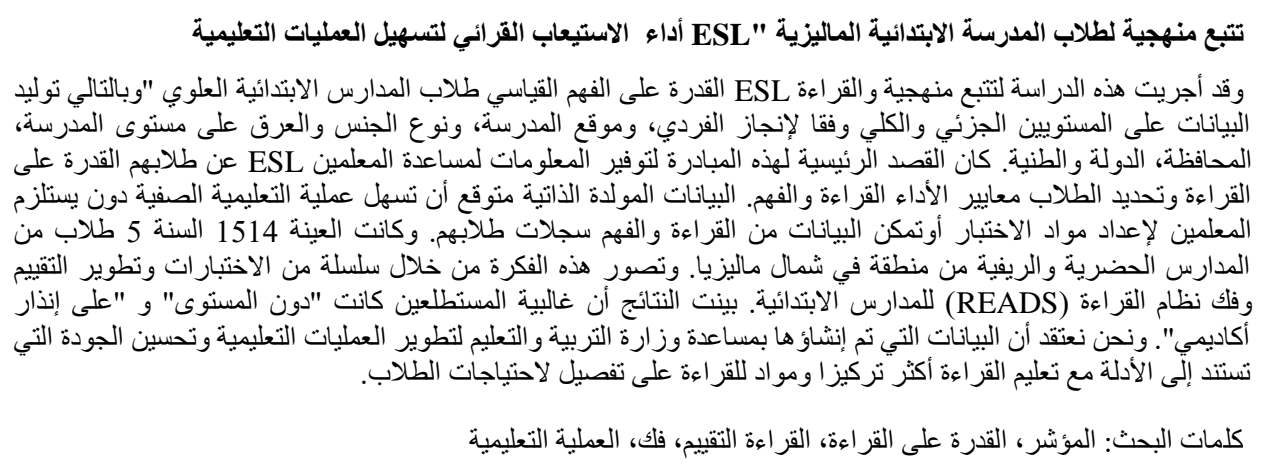

International Journal of Instruction, January $2016 \bullet$ Vol.9, No.1 